\title{
Plant Phosphate Nutrition and Environmental Challenges
}

\author{
Mohammad Ali Malboobi, Ali Samaeian, Mohammad \\ Sadegh Sabet and Tahmineh Lohrasebi
}

Additional information is available at the end of the chapter

http://dx.doi.org/10.5772/53424

\section{Introduction}

Since the ancient times, food production was exercised in farms where animals and plants were grown together (Figure 1). However, as a part of Green Revolution, the use of synthetic fertilizers turned out to be an integrated part of industrial agriculture which has progressively encouraged disintegration between cropping and animal husbandry. As a result, the consumptions of fertilizers have remarkably increased since half a century ago [1]. Indeed, disruptions in the cycles of nutrients have brought about environmental challenge that caused irreversible damages to natural ecosystems while reasonably justified by the real needs for food security for growing human population. As one of the main challenges in the world of agriculture, provision of phosphorus (P) for plant nutrition requires a closer look from several points of views.

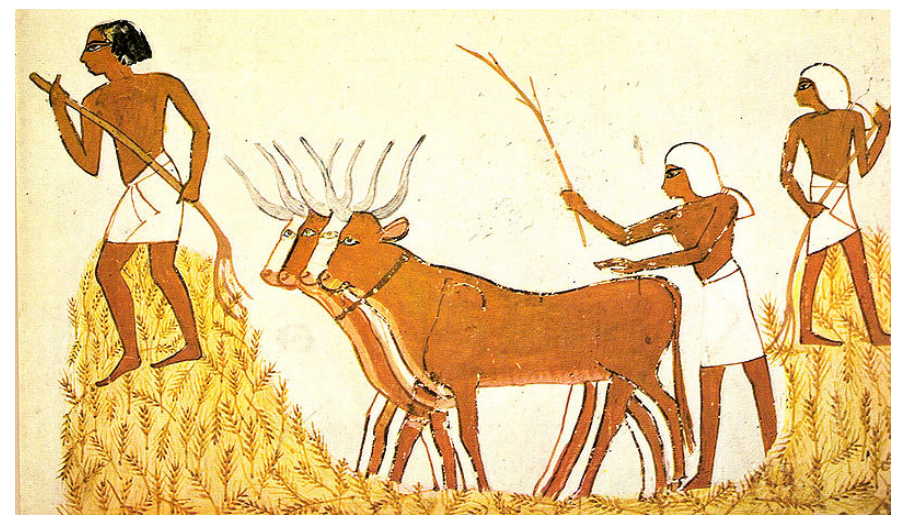

Figure 1. Painted grain and livestock growing together in ancient Egypt. 
In this chapter, we firstly explain the importance of $\mathrm{P}$ in living organisms and the evolved adaptive mechanisms, particularly from the molecular and genomic aspects. Subsequently, the cycle of exchanging $\mathrm{P}$ between physical and biological worlds will be described to show the extent of disturbance by current agricultural practices. Then, possible solutions to the experienced problems in industrialized agriculture will be discussed. The needs for introducing less-energy demanding production and consumption methods for P provision and the use of new generation of fertilizers, particularly organic and biological ones in combination with chemical $\mathrm{P}$ fertilizers will be described in details to address integrative measures for sustainable agriculture.

\section{Pi importance}

$\mathrm{P}$, in the form of phosphate ion $(\mathrm{Pi})$, is the most vital element for all living organisms playing major roles in the structures of essential biomolecules such as nucleic acids, phospholipids and phosphosugars, in almost all metabolic reactions including photosynthesis and respiration, in energy delivering molecules such as ATP, ADP or NADPH and in transduction of signals within the cells. To ensure functional metabolic reactions, Pi homeostasis must be kept between 5 to $20 \mathrm{mM}$ in the cytoplasm. Plants absorb $\mathrm{P}$ only in its soluble inorganic form of $\mathrm{Pi}_{1} \mathrm{H}_{2} \mathrm{PO}_{4}{ }^{-}$or $\mathrm{HPO}_{4}{ }^{2-}$, which occur in the soil between 0.1 to $1 \mu \mathrm{M}$ [2-4]. Therefore, it is one of the most needed nutrients for plant growth and development and considered as a major limiting factor in crop yield.

\section{Soil Pi and plants uptake}

Most soils contain a significant amount of P compounds, ranging from 200 to $3000 \mathrm{mg} / \mathrm{kg}$, averaged at $1200 \mathrm{mg} / \mathrm{kg}$ [5]. P compounds in soil comprise a wide variety of organic and inorganic forms [6]. However, only a small proportion (generally less than $1 \%$ ) is immediately available to plants as free $\mathrm{Pi}$. The majority of inorganic compounds are predominantly associated with calcium (Ca) in alkaline soils or with iron (Fe) and aluminum (Al) in acidic soils [6]. Organic Pi accounts for 30 to 80 percent of soil P, among them monoester P occurs predominantly as cation derivatives of inositol hexakisphosphates (mainly as phytate), whereas sugar phosphates and diester phosphates (e.g. nucleic acids and phospholipids) constitute only a small proportions $(\sim 5 \%)[7,8]$. Factors that contribute to the accumulation and turnover of different forms of in/organic $\mathrm{P}$ in soil are complex and controlled by various competing processes that have been the subject of several reviews [6, 9-13].

High concentrations of $\mathrm{Pi}$ are generally found in the surface layer of soil profiles or in nutrientrich patches. Plants usually produce more roots in the surface soil than the subsoil. For instance, an analysis of traits associated with the rate of Pi uptake in wheat showed that root length density in the surface soil was the most important trait for Pi acquisition [14]. Because of that, drying the surface soil can cause ceased Pi uptake or 'nutritional drought' [15].

Low solubility of Pi in water (0.5 mg/lit), slow diffusion rates of Pi in soil (10-12 to $\left.10^{-15} \mathrm{~m} / \mathrm{s}\right)$ and limited capacity for replenishment of soil Pi-solution are major factors that contribute to 
its deficiency in plants [4, 16-18]. It is also influenced by biological processes such as the hydrolysis of ester bonds in organic Pi compounds by phosphatase enzymes.

The uptake of Pi from soil by plants depends on both the rate of diffusion of Pi towards roots and the growth of the root system to access unexploited soil [19]. Roots rapidly deplete $\mathrm{Pi}$ in the soil solution so that its concentration at the root surface is estimated around 0.05$0.2 \mathrm{mM}$ [19]. Although this establishes a Pi-diffusion gradient from the rhizosphere to bulk soil [19-21], low Pi diffusion rate effectively limits its uptake [22]. It is believed that proper application of the fertilizers not only provides $\mathrm{Pi}$, but also promotes root growth into unexploited soil [18].

\section{Pi uptake and reallocation in plants}

Under experimental conditions, both high and low affinity Pi uptake mechanisms have been recognized in plants $[23,24,25]$. Nevertheless, it is generally accepted that if Pi level is within the micromolar range $(1-10 \mu \mathrm{m})$, which corresponds to Pi concentrations in most cultivated soils, the high-affinity transporters handles Pi uptake. The $K_{m}$ for high-affinity transporters varies from 1.8 to $9.9 \mu \mathrm{M}$ [25]. It is an energy mediated co-transport process, driven by protons generated by a plasma membrane $\mathrm{H}^{+}$-ATPase [23, 26]. Additional evidence for the involvement of protons in Pi uptake comes from the use of inhibitors that disrupts proton gradient across membranes causing the suppression of Pi uptake [25,27].

Both experimental data and genome sequence analyses indicate that plants possess families of Pi transporter genes [24, 28-31]. Current data suggest that members of the PHT1 Pi transporter family mediate transfer of Pi into cells, whereas members of the PHT2, PHT3, PHT4, and pPT families are involved in Pi transfer across internal cellular and organelle membranes [32-35].

Members of the PHT1 Pi transporter gene family have been identified in a wide range of plant species including Arabidopsis, rice, medicago, tomato and soybean [28, 36-41]. Analysis of Arabidopsis whole genome sequences revealed a set of nine PHT1 transporters. Eight of them expressed in roots from which four are expressed in the epidermal cells. In contrast, there is less redundancy in the aerial tissues [42]. In rice, at least 10 of the PHT1 transporters are expressed in roots [40].

Overlapping expression patterns have also been reported for the PHT1 Pi transporters in other plant species [38,41,43-46]. The function of some PHT1 transporters have been analyzed either by expression in yeast Pi transport mutants or in plant cells [27,30,36,43,47]. In Arabidopsis two Pi transporters, PHt1;1 and PHt1;4, mediate $75 \%$ of the Pi uptake capacity of the roots system in a wide range of environmental conditions [48].

After uptake into the roots, Pi moves symplastically from root surface to xylem at a rate of about $2 \mathrm{~mm} / \mathrm{h}$ and to the other organs afterwards [2]. Entering into the xylem for long-distance translocation to the shoot is facilitated by another set of transporter-like proteins [49-50]. Most of the absorbed Pi by the roots is transported through xylem to growing leaves of Pi-fed plants. In Pi-starved plants. Stored Pi in older leaves is retranslocated to both younger leaves 
and growing roots, from where Pi can again be recycled to the shoot [51]. Consequently, the uptake and allocation of $\mathrm{Pi}$ in plants requires multiple transport systems that must function in concert to maintain homeostatic level of it throughout the plant tissues [52].

\section{Plant adaptive strategies toward low Pi}

\subsection{Morphological changes in root architecture}

Factors that affect the initiation and activity of the meristems have a large effect on the three dimensional patterns of roots in space, the so-called Root System Architecture (RSA) [53] which is greatly influenced by surroundings soil and particularly the availability and distribution of nutrients, including Pi [54]. Several studies demonstrated that Arabidopsis thaliana exposed to low available Pi have reduced primary root growth and at the same time increased lateral root formation and growth and, also, root hair production and elongation [55]. Under sever Pi starvation, root hairs disappeared entirely in tomato [56]. Modification of RSA enable plant roots to explore the upper parts of the soil, a strategy described as 'topsoil foraging' [57]. Symbiotic associations with fungi (Vesicular-Arbuscular Mycorrhizae; see below) and formation of cluster roots are adaptive responses to increase $\mathrm{Pi}$ uptake in many plants which allow competent exploration of soils for fixed Pi [58-63].

Detailed analysis demonstrated some differences in RSA responses among ecotypes [64]. Among 73 Arabidopsis ecotypes, half showed reduced primary root growth on low Pi suggesting that root growth inhibition is determined genetically rather than being controlled metabolically only [65].

The first visible event upon Pi starvation is reduction of primary root cell elongation followed by a reduction of cell division as traced by rapid repressonof the cell cycle marker CYCB1;1. This is accompanied by a loss of quiescent center identity as detected by the QC46 marker [66].

Transcriptomics approach as well as mutations analyses have revealed an inventory of genes which are repressed or induced during Pi starvation. For example, PRD (Pi root development) gene is rapidly repressed in roots under low Pi conditions [67-70]. In this context, PRD repression mediated primary root growth arrest [66].

\subsection{Metabolic adaptations to Pi deficiency conditions}

As mentioned above, $\mathrm{Pi}$ is an essential macronutrient that plays a central role in virtually all metabolic processes in plants. This was clearly illustrated for Pi-induced inhibition of a major regulatory enzyme of starch biosynthesis, ADPGlc pyrophosphorylase. Similarly, a vacuolar acid phosphatase (APase) displayed strong activity inhibition by sufficient Pi [7173]. Conversely, the depletion of vacuolar Pi pools by extended Pi deprivation effectively relieved the inhibition of some APase expressions [74].

A common feature of the plant response to long-term Pi starvation conditions is the development of dark-green or purple shoots due to anthocyanin accumulation. It is brought 
about by Pi-induced biosynthetic enzymes in each step of the pathways leading to the synthesis of cyanidin, pelargonidin, flavonoids and anthocyanin [74-76].

A reduction in the phospholipid content of Pi-starved plant membranes coincided with increased sulfolipid sulfoquinovosyldiacylglycerol and galactolipid digalactosyldiacylglycerol membrane lipids. SQD1 and SQD2 are Pi starvation inducible enzymes required for sulfolipid biosynthesis in Arabidopsis [74,77]. Consistently, an Arabidopsis sqd2 T-DNA insertional mutant showed reduced growth under Pi starvation conditions [78]. Galactolipid digalactosyldiacylglycerol accumulation was reduced in the roots of Pi-starved pldz1 single and pldz1/pldz2 double mutants [79]. PLDz generates phosphatidic acid that can be dephosphorylated by an APase to release $\mathrm{Pi}$ and diacylglycerol serving as a second messenger. The latter activates a protein kinase-mediated protein phosphorylation cascade which controls root growth. In contrast to PLDz function in roots, a non-specific phospholipase $\mathrm{C} 5$ is responsible for phospholipid degradation in leaves during Pi starvation [80].

As a consequence of harsh Pi stress, large (up to 80\%) reductions in intracellular levels of ATP, ADP, and related nucleoside phosphates also occur [81-82]. A noticeable feature of plant metabolism alterations is that some step in metabolic pathways could be bypassed to reduce dependence on $\mathrm{Pi}$ or ATP. This was confirmed by silencing of genes encoding enzymes traditionally considered to be essential. The growth and development of resulting transgenic plants were more or less normal [82] while it was expected to have inhibition of C flux. Protein phosphorylation and glycosylation were found responsible for controlling the activity and/or subcellular targeting of some enzymes involved in bypassed metabolic reactions in response to Pi deprivation [83-85].

\subsection{Acid Phosphatases and Pi recycle}

A key plant response to Pi deprivation is the up-regulation of a large number of intracellular and secreted APase enzymes that hydrolyze Pi from a broad range of Pi compounds. Secreted APases are believed to function in scavenging nutritional Pi from many exogenous organic Pi substrates, including phytate, RNA, DNA, ATP, 3-phosphoglycerate, and various hexose phosphates that typically constitutes $20-85 \%$ of $\mathrm{P}$ compounds in soil [17,73-75,86-88]. Similarly, intracellular APases scavenge and remobilize Pi from expendable intracellular Pi monoesters and anhydrides. This is accompanied by marked reductions in levels of the cytoplasmic Pi-containing metabolites during extended Pi deprivation [75,81].

It is noteworthy that APase activity in rhizosphere or soil solution may also originate from fungi such as Aspergillus [89] and mycorriza [90] or from bacteria [89,90]. Microorganisms may produce both acid and alkaline phosphatase [89] while plants secrete APases only $[89,92]$.

\subsection{Organic acid biosynthesis and secretion}

An adaptive strategy for $\mathrm{Pi}$ acquisition is the excretion of proton and organic acids from roots which results in acidification of rhizosphere. The importance of this mechanism was 
unknown until plasma membrane $\mathrm{H}^{+}$-pumping ATPases were shown to be involved in plant adaptation to Pi starvation [93]. Acidification was also correlated with the up-regulation of novel membrane channels needed to transport anions such as citrate and malate from root cells into the rhizosphere [94]. Organic acid excretion results in the chelating of metal cations that immobilize Pi (e.g. $\mathrm{Ca}^{2+}, \mathrm{Al}^{3+}, \mathrm{Fe}^{2 / 3+}$ ), thus, increasing free Pi concentrations in soil upto 1000-fold. Acidification of rhizosphere also enhances the hydrolysis of organic Pi by secreted APases. As well, organic acids could function as carbon source for symbiotic rhizobacteria that facilitate root Pi acquisition $[17,74,75,86]$.

The amounts of exuded carbon as organic acids can be enormous, ranging from $10 \%$ to greater than $25 \%$ of the total plant dry weight [75]. Enhanced synthesis of organic acids in Pi-starved plants has been correlated with up-regulation of phosphoenolpyruvate carboxylase and its activation by reversible phosphorylation as well as malate dehydrogenase and citrate synthase and elevated rates of dark $\mathrm{CO}_{2}$ fixation $[75,83]$.

\section{Genomic analysis of Pi adaptation mechanisms}

As sessile organisms, plants stand on their own potential to retrieve Pi from their surrounding soil and utilize it as efficient as possible. Perhaps, this is why they carry numerous loci encoding APases and Pi transporters. Some representative genomes are shown in Table 1.

\begin{tabular}{lccc}
\hline Organism & Genome size $\mathbf{( M b )}$ & APases & Pi transporters \\
\hline Oryza sativa & 450 & 40 & 14 \\
Arabidopsis thaliana & 125 & 58 & 15 \\
Glycine max & 975 & 128 & 35 \\
Populus trichocarpa & 10 & 51 & 22 \\
\hline
\end{tabular}

Table 1. Genome size and the number of APase and Pi transporter-encoding genes in four plant genomes with annotated sequenced.

Genome-wide profiling methods has been employed to compare the transcriptional profiles of Pi-starved and Pi-fed plants [67-69,95-99]. These studies have shown that the changes in gene expression can be detected within hours after exposure to Pi starvation $[67,68,95]$. Wu et al. [67] found that within $72 \mathrm{~h}$ from the onset of Pi starvation, the expression of 1800 of 6172 surveyed genes were changed over two-fold, which include more than 100 transcription factors and cell signaling proteins. Furthermore, differential expression patterns in leaves and roots demonstrated distinct responses to Pi starvation in those organs. A similar conclusion was obtained from the microarray analysis of the Pi-starved rice seedlings [100]. Using an Arabidopsis whole genome Affymetrix chip which includes 22,810 genes, Misson et al. [68] found that the expression of 612 genes were induced while 254 genes were suppressed under Pi-limiting conditions. In addition to the Pi transporters, RNase and APase genes, the induced genes include those that function in sulfate and iron transport and homeostasis, Pi salvaging from organic compounds, phospholipids degradation and galacto- and sulfolipid synthesis, anthocyanin synthesis, phytohormone 
responses, signal transduction, transcriptional regulation, protein degradation, cell wall metabolism and so on. The suppressed genes are involved in lipid synthesis, reactive oxygen controlling and protein synthesis. In another research, Morcuende et al. [69] showed $\mathrm{P}$ deprivation led to transcriptional alterations in over 1000 genes involved in Pi uptake, the mobilization of organic $\mathrm{Pi}$, the conversion of phosphorylated glycolytic intermediates to carbohydrates and organic acids, the replacement of phospholipids with galactolipids and the repression of gene implicated in nucleotide/nucleic acid synthesis which were reversed within $3 \mathrm{~h}$ after Pi re-supply. In addition, analysis of metabolites confirmed that $\mathrm{P}$ deprivation leads to a shift towards the accumulations of carbohydrates, organic acids and amino acids. Pi deprived plants also showed large changes in the expression of many genes involved in secondary metabolism and photosynthesis. Hammond et al. [101]used an oligonucleotide potato microarray to investigate the transcriptional profile of potato leaves under Pi deficiency and compare their data with previously described transcriptional profiles for the leaves of Arabidopsis and rice. They identified novel components to these profiles, including the increased expression of potato patatin genes- with potential phospholipase A2 activity- in the leaves of Pi deficient potatoes. A set of 200 genes were identified that show differential expression patterns between fertilized and unfertilized potato plants.

Müller et al. [102] investigated the effect of interaction of Pi and sucrose signals on the gene expression pattern in Arabidopsis. They found several genes that were previously identified to be either sugar-responsive or Pi-responsive genes. In addition, 150 genes were synergistically or antagonistically regulated by the two signals.

In a comprehensive analysis, Lin et al. [103] conducted time course microarray experiments and co-expression-based clustering of Pi-responsive genes by pair wise comparison of genes against a customized data base. Three major clusters enriched in genes functioning in transcriptional regulation, root hair formation and developmental adaptations were distinguished in this analysis. The genome-wide transcriptional approach may be used to infer inclusive scenarios for involved mechanisms in the signaling and adaptation of plants to Pi deficiency.

\section{Pi sensing and gene expression}

Metabolic adjustments to Pi limitation are largely cellular responses to sensed by internal Pi status which trigger a systemically integrated regulating mechanisms involving microRNAs, non-coding RNAs and $\mathrm{PHO}_{2}$ downstream of PHR as revealed in recent studies. PHR1, a MYB transcription factor, binds to the promoters of most of the Pi-responsive genes that are positively or negatively affected by Pi starvation [104]. Despite its central role in controlling the expression of numerous Pi-responsive genes, the phr1 mutant showed no major phenotypic defects except for a slight difference in the root-to-shoot ratio and root hair induction [105]. Indeed, PHR1 works with another MYB factor, PHL1, to control most transcriptional activations and repressions in responses to Pi deficiency [104]. Furthermore, about two thirds of the genes repressed in Pi-deprived wild type seedlings were markedly de-repressed in Pi-starved phr1phl1 double mutants [104]. 
In Arabidopsis, a number of miRNA molecules have been shown to be specifically and strongly induced by Pi limitation, including miRNA399, miRNA778, miRNA827 and miRNA2111[106-108], though only the role of miRNA399 in the regulation of Pi homeostasis has been elucidated [77,109]. miRNA399 is a component of the shoot-to-root Pi-deficiency signaling pathway that moves from shoot to root via the phloem where it targets the transcripts of PHO2 $[103,110]$. The repression of PHO2 expression by miRNA399 causes upregulation of root Pi transporters (e.g. PHT1;8 and PHT1;9).

The Pi-signaling network also involves IPS (Induced by Pi Starvation) genes that carry short open reading frames [111-112]. It is postulated that their transcripts operate by a mechanism called 'target mimicry' as they contain a conserved 23-bp region complementary to miRNA399 and to fine-tune the $\mathrm{PHO}_{2}-$ miRNA399 pathway [113]. Since homologs of Arabidopsis IPS and $\mathrm{PHO}_{2}$ genes are present in numerous other plants such a mechanism is probably widespread in plants [114].

The role of miRNAs and non-coding RNAs appear to be extended to a possible role in its coordination with homeostasis of $\mathrm{Pi}$ and also other nutrients. For example, a hypothetical role was attributed to miRNA827, in the cross-talk between Pi-limitation and nitratelimitation signaling pathways that affect anthocyanin synthesis [108]. In a survey on small RNAs showing differential expression, miRNA169, miRNA395, and miRNA398 were found to be suppressed in response to Pi deficiency while they also responded to other nutritional stresses [106]. Furthermore, miRNA169 and miRNA398 target genes involved in drought tolerance and oxidative stress response [115]. Suppression of miRNA395 was suggested to up-regulate the expression of APS4 and SULTR2;1 leading to increased sulfate translocation and improved utilization of sulfolipid biosynthesis under Pi-deficient conditions [115].

Taken together, the genome-wide surveys affirm the participation of miRNAs in coordination of homeostatic pathways of Pi and possible links between them and metabolic adjustment [106].

\section{Limited Pi resources}

Despite the existence of high amounts of $\mathrm{P}$ in the soil [5], the concentration of available Pi in many soil solution averages at about $1 \mu \mathrm{M}$ and seldom exceeds $10 \mu \mathrm{M}$ [2] which is far below the cellular $\mathrm{Pi}$ concentrations $(5-20 \mathrm{mM})$ required for optimal plant growth and development [73]. Such a limitation often lead to reduced productivity in natural ecosystems as well as cropping systems, unless it is supplied as fertilizer [74-75]. Whilst our limited global Pi reserves are non-renewable, $\mathrm{P}$ in many agricultural soils is being building up. This is because 80 to 90 percent of $\mathrm{Pi}$ applied as fertilizer is fixed by soil particles or compounds, rendering it unavailable for plants.

\section{Types of Pi mines}

There are over $200 \mathrm{P}$ minerals existing on the earth but only a few can be used for commercial extraction of Pi [61]. Phosphate Rocks (PR) is the commercial term applied to all 
$\mathrm{Pi}$ bearing minerals suitable for $\mathrm{Pi}$ production. The primary $\mathrm{Pi}$ minerals in $\mathrm{PR}$ are phosphorites that include fluor-apatite $\left(\mathrm{Ca}_{10}\left(\mathrm{PO}_{4}\right)_{6} \mathrm{~F}_{2}\right)$, Hydroxy-apatite $\left(\mathrm{Ca}_{10}\left(\mathrm{PO}_{4}\right)_{6}(\mathrm{OH})_{2}\right.$, carbonate-hydroxyl-apatites, and francolite (Ca10-x-y Nax $\left.\mathrm{Mgy}\left(\mathrm{PO}_{4}\right)_{6}-\mathrm{z}\left(\mathrm{CO}_{3}\right)_{\mathrm{zF}} \mathrm{C} \cdot 4 \mathrm{zF} 2\right)$ which is a carbonated-substituted form of apatite mainly found in marine environments [116].

In PR industry the grade of the rocks are mostly reported as the percentage of $\mathrm{P}$ pentoxide $\left(\mathrm{P}_{2} \mathrm{O}_{5}\right)$. Three major resources that can be profitably recovered today are as below [116-117]:

1. Sedimentary Pi deposits which are widespread throughout the world, occurring almost on all continental shelves. Francolite and apatites are deposited in layers that might cover thousands of square miles in several chemical compositions and a wide range of physical forms $[116,118]$.

2. Igneous Pi deposits which are mostly found in continental shelf and on seamounts in the Atlantic and Pacific oceans (Russia, Canada, Brazil and South Africa). Their exploitation is economically non-feasible so that they have mostly remained untouched [118].

3. Biogenic deposits, also known as island $\mathrm{Pi}$, which are mainly old bird and bat droppings built up.

About $80 \%$ of world Pi production comes from non-renewable sedimentary reserves, 15 to $19 \%$ from igneous and about 1-5\% from biogenic and other deposits such as island Pi which are near total depletion due to over exploitation during the past decade [116].

\section{Geographic distributions of Pi rocks}

Today, PR is produced in over 40 countries, with 12 countries producing over $92 \%$ of the world's total production [118]. US alone produce over $28 \%$ of the total production followed by China, Morocco and Russia. Among them, four major producers of PR (the United States of America, China, Morocco and Western Sahara, and the Russian Federation) produced about 72.0 percent of the world total. Twenty other countries produced the remaining 6-7 percent of world production [119].

\section{Methods of Pi production}

Production of fertilizers began in early $19^{\text {th }}$ century when crushed bones were treated with acid and applied to soil. Since 1945 mining of PR was increased from 11.2 Mt to $145 \mathrm{Mt}$ in 1999 [120]. This was translated to increasing production rate of Pi fertilizers (as $\left.\mathrm{P}_{2} \mathrm{O}_{5}\right)$ from 4 Mt by 1940 's to over $42 \mathrm{Mt}$ annually today [121]. Ever since new technologies has been evolving to maximize the production rate and purity of the fertilizers. Here a brief description of the major production methods is given.

\subsection{Wet process}

The wet process or hemihydrate process is the newest and dominant production method used due to its ease, lesser investment size, energy efficient and higher yield [122]. Basically, 
this is the process where PR is treated with sulfuric acid to hydrolyze apatite minerals. Other acids can be used to harvest Pi depending on the costs and desired final product. For example, phosphoric acid addition yields TSP as the final product. Using of nitric acid and hydrochloric acid has also been reported but never industrialized. Phosphogypsium and silicon fluorine or HF are as the main side product in this method. Sulfuric acid added to PRs forms the soluble monocalcium Pi. This product can either go to the fertilizer production (i.e. MAP or DAP) or to concentrated forms for other applications [122-123]. Concentrating the product by evaporation can yield up to $53 \%$ phosphoric acid solution. The pollution of current technology wastes (4-5 tons phosphogypsium per one ton of $\mathrm{P}_{2} \mathrm{O}_{5}$ ) signifies the processing costs for the industry.

\subsection{Thermal process}

Thermal process is an older technology that is used in only a few factories in the world. High electricity and water consumption as well as higher investment size and lower product yield makes such process less desirable for investors. This process can be performed in desired scales, but requires detailed financial feasibility estimation depending on the production site location [122]. Before heating, Pi rock is converted to 1-2 cm pellets by wet granulation and sintering to prevent blocking of furnace. Next step involves mixing with cokes (reducing agent) and $\mathrm{SiO} 2$ (for slag formation) before feeding into furnace. Heating at $1500^{\circ} \mathrm{C}, \mathrm{Pi}$ is reduced to $\mathrm{P} 4$ in gaseous state which is condensed afterward. Remaining $\mathrm{CaO}$ combines with $\mathrm{SiO}_{2}$ to form liquid slag that might be used for road construction [124].

\subsection{Bioprocess}

Bioprocessing of Pi rocks involves treatment of apatites with Pi solubilizing bacteria. This controlled fermentation process requires presence of a bacterial energy supply such as sugars which is consumed to produce organic acids to break down the PRs [125]. Optimization of this process is still under investigation of many scientific and financial institutes due to its promising outlook.

Bioprocessing of insoluble soil Pi compounds is also carried out directly in agricultural fields by the use of biofertilizers (see below) which converts a portion of precipitated fertilizers as well as natural occurring insoluble Pi. This method is extremely feasible with regards of purchasing, application and higher crop yields [126].

\section{Emergence of Pi fertilizers}

As mentioned earlier in this chapter, Pi has been found to be the limiting macronutrient in most agricultural soils. The first surveys that revealed such deficiency was a simple study during early $19^{\text {th }}$ century in England [127]. At that time the only source of artificially added Pi to the agricultural soils was farmyard manure, which resulted in higher crop yields near manure production sites. It was only a matter of time before it was realized that crushed bones might have a positive result on crop yield on some specific types of soils. Treating the 
crushed bones with sulfuric acid to produce superphosphate was followed by the same treatment of PRs to produce current Pi fertilizers which was the beginning of a new era in the world agriculture history [127]. Since then, Pi fertilizers production processes, molecular types, application methods and feasibility assessments have been the subject of a wide range of researches and analyses. Table 2 summarizes popular Pi fertilizers that are currently used [128].

\section{Trend of Pi usage in the world}

In 2006, $167 \mathrm{Mt}$ of PR were mined in the world, while China alone was responsible for $56 \mathrm{Mt}$ of it. $23 \%$ of the total PR production was directly used as fertilizers which equals $12 \mathrm{Mt}_{2} \mathrm{P}_{5}$ per year. Only $6 \%$ was used for production of elemental $\mathrm{P}$, and almost the rest went through the wet process for production of phosphoric acid, which in turn is mostly (88-95\%) used up for Pi fertilizers. World's total Pi supply $\left(\mathrm{P}_{2} \mathrm{O}_{5}\right)$ has been estimated to rise from $42 \mathrm{Mt}$ in 2010 to $45 \mathrm{Mt}$ in 2015 (Table 3) [121]. It is expected that P fertilizer supply will have an increased trend of $3.2 \%$ annually with the major Pi balance (production minus consumption) surplus in North America and Africa and deficit in Latin America and Asia. With the current rate of consumption, various estimates showed that recoverable Pi mine will be vanished in 50 to 100 years [129].

\begin{tabular}{|c|c|c|c|c|c|}
\hline Material & $\mathbf{P}$ & $\mathbf{N}$ & $\mathbf{K}$ & $S$ & $P$ compound \\
\hline Superphosphoric acid & $\begin{array}{c}30 \text { to } \\
35\end{array}$ & ----- & ----- & ----- & $\mathrm{H}_{3} \mathrm{PO}_{4}$ \\
\hline $\begin{array}{l}\text { Wet Process phosphric } \\
\text { acid }\end{array}$ & $\begin{array}{c}23 \text { to } \\
24\end{array}$ & ----- & ---- & ----- & $\mathrm{H}_{3} \mathrm{PO}_{4}$ \\
\hline $\begin{array}{l}\text { Concentrated } \\
\text { superphosphate (TSP) }\end{array}$ & 20 & ----- & ----- & 1 to 1.5 & $\mathrm{Ca}\left(\mathrm{H}_{2} \mathrm{PO}_{4}\right)_{2}$ \\
\hline $\begin{array}{l}\text { Diammonium } \\
\text { phosphate (DAP) }\end{array}$ & $\begin{array}{c}20 \text { to } \\
21\end{array}$ & $\begin{array}{c}18 \text { to } \\
21\end{array}$ & ----- & $0-2$ & $\left(\mathrm{NH}_{4}\right)_{2} \mathrm{HPO}_{4}$ \\
\hline $\begin{array}{l}\text { Monoammonium } \\
\text { phosphate (MAP) }\end{array}$ & $\begin{array}{l}21 \text { to } \\
24\end{array}$ & $\begin{array}{c}11 \text { to } \\
13\end{array}$ & . & 0 to 2 & $\mathrm{NH}_{4} \mathrm{H}_{2} \mathrm{PO}_{4}$ \\
\hline $\begin{array}{l}\text { Normal } \\
\text { superphosphate }\end{array}$ & 7 to 10 & ----- & ----- & 12 & $\mathrm{Ca}\left(\mathrm{H}_{2} \mathrm{PO}_{4}\right)_{2}$ \\
\hline Phosphate Rock & $\begin{array}{c}12 \text { to } \\
18\end{array}$ & ---- & ----- & ---- & $\begin{array}{c}{\left[\mathrm{Ca}_{3}\left(\mathrm{PO}_{4}\right)_{2}\right]_{3} \cdot \mathrm{CaF}_{x} .} \\
(\mathrm{CaCO})_{x} \cdot\left(\mathrm{Ca}(\mathrm{OH})_{2}\right)_{x}\end{array}$ \\
\hline $\begin{array}{l}\text { Monopotassium } \\
\text { phosphate }\end{array}$ & & ----- & 35 & ---- & $\mathrm{KH}_{2} \mathrm{PO}_{4}$ \\
\hline $\begin{array}{l}\text { Dipotassium } \\
\text { phosphate }\end{array}$ & & ----- & 54 & ----- & $\mathrm{K}_{2} \mathrm{HPO}_{4}$ \\
\hline
\end{tabular}

Table 2. Commonly used Pi fertilizers and the percentage of each elements (quoted from Havlin and Beaton [128]). 
An IFDC estimates shows that resources of unprocessed PR of varying grades could be as high as $290 \mathrm{Mt} \mathrm{[130]} \mathrm{that} \mathrm{could} \mathrm{become} \mathrm{reserves} \mathrm{once} \mathrm{all} \mathrm{high} \mathrm{grade} \mathrm{PR} \mathrm{are} \mathrm{depleted.} \mathrm{Even} \mathrm{if}$ this takes place, the price of Pi would not be affordable for many poor farmers and still pollution because of $\mathrm{Pi}$ accumulation and associated wastes in the soil and water are of concerns.

\begin{tabular}{lcccccc}
\hline Year & 2010 & 2011 & 2012 & 2013 & 2014 & 2015 \\
\hline Supply & 39600 & 42094 & 43966 & 45011 & 46439 & 47788 \\
Demand & 41700 & 41679 & 42562 & 43435 & 44245 & 45015 \\
Potential balance & -2100 & 415 & 1404 & 1576 & 2194 & 2773 \\
\hline
\end{tabular}

Table 3. World Pi supply, demand and balance according to FAO report (2008) [119].

It is noteworthy the extracted phosphoric acid, so-called green or wet process acid, contains upto $24 \%$ elemental $\mathrm{P}$ and is produced from the reaction of sulfuric acid and PR. It is used for agronomics means either by direct application to more alkaline soils or by reaction with PRs for partial or complete acidulation. Phosphoric acid is also produced by electric furnace to produce elemental $\mathrm{P}$ that in turn reacts with $\mathrm{O}_{2}$ and water to make phosphoric acid. This type of phosphoric acid, called white acid, is purified to make technical and food grades which is mostly used for non-agricultural purposes such as soft drinks due to its higher purity and expensive production costs [128].

\section{Effect of $P$ fertilizers on crop yields}

Soil scientists recognize three kinds of Pi: (1) deposited Pi as chemical compounds in the soil; (2) available Pi or free Pi ion in the soil; and (3) absorbable Pi or free Pi ion in vicinity of root. Even though the average use of $\mathrm{P}_{2} \mathrm{O}_{5}(19 \mathrm{~kg} / \mathrm{ha})$ has been less than recommended amounts in the literature $(30 \mathrm{Kg} / \mathrm{ha})$ [131], it has resulted in significant increase in crop yields around the world. For example, an increase between 9 to $60 \%$ compared to control was observed in Middle East countries on barley, wheat, and chickpea. Productivity Indexes of cereal crops were as high as 11.1 when up to $90 \mathrm{~kg} / \mathrm{ha} \mathrm{P}_{2} \mathrm{O}_{5}$ were added. Data on oil crops shows productivity index upto 6 in groundnut and mustard. In Indonesia, upto 10 fold increase was observed after soluble Pi was added to soybeans [131]. Such examples are very easy to find in the literatures dated early $19^{\text {th }}$ to $20^{\text {th }}$ centuries when the application of $\mathrm{Pi}$ fertilizers were becoming dominant. The resultant high yield is accompanied by Pi removal of $6 \mathrm{~kg} / \mathrm{ha}$ for cereals and $20 \mathrm{Kg} / \mathrm{ha}$ for other crops from soil [61].

\section{The fate of Pi fertilizers in soil}

Two contrasting challenges of higher crop yield and environmental concerns necessitate tracing the fate of Pi fertilizer added to soil. As the Pi fertilizer granule or droplet is added to the soil, the moisture penetrates its way into the fertilizer. This results in the release of export of Pi into the soil which might expand as far as 3 to $5 \mathrm{~cm}$ from an average size granule [128]. As long as the original salt remains, a saturated solution is maintained around 
the granule, which in turn absorbs water, increasing the soil moisture. In these areas Pi uptake can take place efficiently by plants. Depending on type of soil and its cations composition, the released Pi can re-precipitate within a few days or weeks [127-128]. This behavior indicate the proper time of Pi fertilizer application in order to reduce the chance of $\mathrm{Pi}$ accumulation in the soil. The use of such information also helps calculating the correct amount of Pi that should be applied for maintaining the P-level of the soil after a harvesting season which is extremely important for balanced fertilization. It has been shown repeatedly no increase in yield is detected when Pi fertilizers are over-used [124,127,128].

\section{Need for Pi preservation and restoration}

Historically, since mid-19th century, the use of local organic matters was replaced by other sources such as guano, deposited bird droppings in remote islands. Growing world consumption rapidly vanished guano resources by the end of $19^{\text {th }}$ century shifting trades to PR. In recent years, the PR production has grown to over 140-160 Mt per year for extraction of about 25 Mt elemental $P$ per year [132].

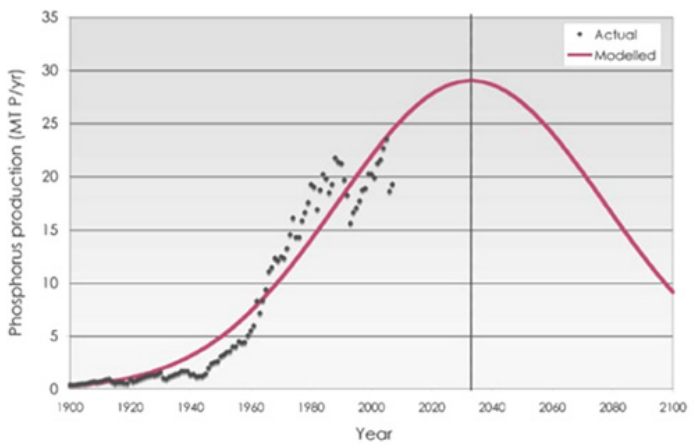

Figure 2. Predicted peak of elemental $\mathrm{P}$ production curve based on actual data in previous years. It illustrates global P reserves are likely to peak around year 2033 when current P production will not be economical any more (Quoted from Cordell et al. [129]).

Since PRs are non-renewable, it is estimated that the economically recoverable reserves will be depleted by the end of this century [129]. The point is that production rate will peak at a maximum when high quality and accessible Pi resources are depleted and mining and processing become quite expensive. As shown in Figure 2, the consumption of $\mathrm{P}$ since $19^{\text {th }}$ century follows a Guassian distribution curve. Assuming the total earth reserve of elemental $\mathrm{P}$ is approximately $3240 \mathrm{Mt}$, then its production will peak at $29 \mathrm{Mt}$ in 2033 as modeled by Cordell et al. [129] (Figure 2). Although the actual timing depends on several conditions to be met, however, this is really alarming if considering that the non-renewable Pi reserves are finite and there is no substitute for PRs. Besides, one might presume that the energy cost will be increased and the average grade of Pi will decrease in future as it was experienced to decline from $15 \%$ to $13 \%$ between 1970 to 1996 [132]. As this challenge silently threaten the food security, a global comprehensive effort is necessary. Web sites such as Pi Knowledge 
Center (http://www.GreenPi.info) or Global Phosphorus Research Initiative (http://www.phosphorusfutures.net) could greatly help worldwide data sharing and collaborations amongst scientists and other players to seek integrative solutions.

\section{Environmental concerns about Pi production}

Removal of massive amounts of soil and extensive washing with huge amounts of water are major changes in the environment of the mining sites and the surrounding regions by themselves. However, the most important issue is disposal of side products that pollute the ecosystem at the stacking sites massively.

Phosphogypsum, the side product of wet process, is deposited in large land areas called gypsum stacks. For the production of $50 \mathrm{Mt}$ of $\mathrm{P}_{2} \mathrm{O}_{5}$ annually, about $250 \mathrm{Mt}$ of gypsum is produced, out of which only 10 percent is used for other purposes (e.g. road construction, cement and housing) and the rest remains stacked [122].

Presence of radioactive materials in side products is another issue for $\mathrm{Pi}$ production industry. PRs contain mainly uranium (20-300 ppm) and thorium (1 to $5 \mathrm{ppm}$ ) and their

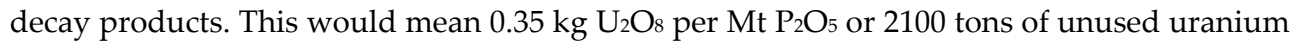
annually [122,133]. About 80 percent of this amount and their decay products are concentrated within the gypsum waste materials in wet process. These could be as high as 7 to $100 \mathrm{pCi} / \mathrm{g}$ uranium, 11 to $35 \mathrm{pCi} / \mathrm{g}$ radium and 1.7 to $12 \mathrm{pCi} / \mathrm{g}$ radon, though radioactivity is different from stack to stack depend on the original PR. The fertilizers themselves might also exhibit radioactivity which might be as high as $33 \mathrm{pCi} / \mathrm{g}$ in US [133]. These concerns are reflected in a final rule of EPA issued in 1992 stating "phosphogypsum intended for agriculture use must have a certificated average concentration of radium-226 no greater than $10 \mathrm{pCi} / \mathrm{g} "[133]$.

\section{Environmental impacts of Pi fertilizers consumption}

The ever growing population of the world has created an enormous pressure to cultivate larger agricultural lands and to increase production yields by improved mechanized methods and usage of fertilizers. Such practices not only alter chemical and physical properties of soils, but also affect macro and micro flora remarkably [122].

Application of Pi fertilizers to soil does not necessarily guarantee plant uptake due to their polycrystalline structure and their tendency to precipitate. An observation showed that if no crop is around, the addition of Pi fertilizer to soil increases the soluble $\mathrm{P}$ within the first couple of years, but it will decrease to a constant level later [127]. Studies in developed countries have also suggested that Pi application might not be as effective as it used to be in the past [125].

In addition to the effect of deposited Pi on the soil structure and microbial flora, leaching of Pi through the erosion of surface soil and organic matters to water streams and lakes cause vast eutrophication [17]. Discharged detergents sodium triphosphates as well as human or animal metabolic wastes must also be accounted for a portion of Pi inputs to surface and 
underground waters [122]. Eutrophication and the consequent over-enrichment of aquatic ecosystems with nutrients, mostly $\mathrm{Pi}$ and nitrate lead to algal blooms and anoxic events that may initiate irreversible environmental damages. Although some lakes have recovered after sources of nutrient inputs were reduced, recycling of enriched Pi from sediments causes lakes to remain eutrophic for years [122].

Recycling of Pi from sewage systems, precision farming and agricultural and industrial treatment units has been exercised in developed countries such as Japan and Germany to reduce such effects [122,124]. Replacing Pi in detergents by aluminum silicate has also been considered as option, despite its much poorer performance. Crystallization of $\mathrm{Pi}$ in wastewater as struvite (ammonium magnesium phosphate), separation of urine and the use of sanitized faecal matters in municipalities have been attempted to recover or reuse wasted $\operatorname{Pi}[129]$.

Cordell et al. [129] warned about the peak time of Pi production (Figure 2) with assumption of PRs are the sole high-value Pi reserves. Taking into consideration the massive amounts of insoluble Pi compounds accumulated in the soil, a straightforward solution could be the utilization of PSMs in the form of biofertilizers [91,126]. Simplified application method and comparable cost of Pi biofertizers on one hand and increased quantity and quality of the yields, on the other hand, have already attracted the attention of farmers.

\section{Cycle of $P$ between the physical and biological worlds}

As shown in Figure 3, P like other mineral nutrients exists in soil, minerals, water as well as living organisms. Over time, geologic events bring ocean sediments to land and weathering

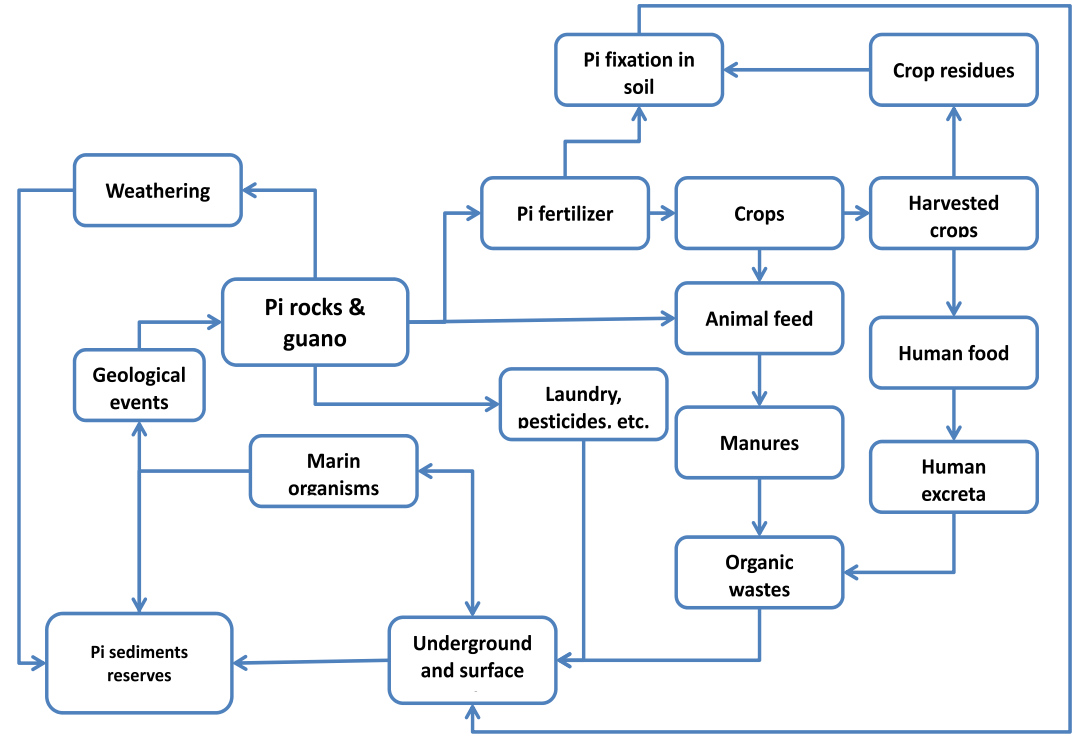

Figure 3. Pi flow through food production and consumption. 
carry $\mathrm{Pi}$ compounds to terrestrial habitats where the land cycles occurs. $\mathrm{Pi}$ is absorbed by plants from soil, consumed by animals and returned to soil as organic matters that slowly released as inorganic $\mathrm{Pi}$ or incorporated in more stable molecules as soil organic compounds. Depending on temperature and moisture, soil microorganisms break down these compounds by secreting organic acids and APase enzymes. Pi leaching due to soil erosion or water run-off to surface or underground waters finally discharge in lakes, seas and oceans where another sub-cycle between marine organisms and Pi sediments occurs. Human action for the utilization of $\mathrm{Pi}$ in fertilizers, pesticides, detergents and food industries are the main sources of disturbance of these natural cycles [134].

\section{Sustainable Pi usage in agriculture}

The assessment of plant response to Pi level in a series of greenhouse pot trials over a wide range of soils with various characteristics established two values of soil $\mathrm{Pi}$, (1) the critical value (Tc) below which it is recommended to apply Pi fertilizers in order to build up soil Pi fertility, and (2) the sufficient value (Ts) above which it is recommended not to apply it over a period of time. For Tc value, available soil Pi (measured by Olson method) ranged from 10 to15 ppm $\mathrm{P}_{2} \mathrm{O}_{5}$ whereas it ranged from 50 to $55 \mathrm{ppm}$ for the Ts value [131]. Of course, it is crucial to provide a certain ratio of each nutrient to establish a proper balance. Legumes need N:P:K nutrients in a ratio of $0: 1: 1,1: 2: 2$ or 1:2:3, root crops, a ratio of 2:1:2, and other crops, a ratio of $2: 1: 1$ or $1: 1: 1$ [131].

An old statistics between year 1960 to 1981 shows that Pi fertilizer consumption has been well established as the share of developed countries in the world was decreased for from $75.1 \%$ to $43.5 \%$ of the world consumption by practicing precision farming while it has increased from 6.5 to $21.3 \%$ in developing countries mainly because of the over usage [125]. The main alternative methods for Pi provision have been described below.

\subsection{Direct application of PRs as Pi fertilizer}

Direct application of $\mathrm{Pi}$ rocks as a source of Pi fertilizer has been practiced since early $19^{\text {th }}$ century. Except for grinding to increase surface area in contact with soil, no other modifications are required to be made which makes it a relatively inexpensive source of Pi. The catch is, however, the lower $\mathrm{Pi}$ content of the rocks and required specific soils conditions such as having acidic $\mathrm{pH}$ (below 5.5) and low exchangeable $\mathrm{Ca}^{2+}$ [116]. Besides, some plants have higher capabilities in mobilization of Pi into their systems. For example, legumes and some crops of Cruciferae family enhance Pi solubilization and uptake by excretion of organic acids that lowers the soil $\mathrm{pH}$ and increases the cation exchange capacity of the soil. Acidifying the rhizosphere, secretion of APases and morphological changes are prerequisite adaptations that enable different crops to salvage Pi from PRs.

\subsection{The use of composted organic materials}

The increasing cost of chemical fertilizers has renewed interest of farmers across all sectors to utilize organic fertilizers as an alternative source of plant nutrients. Composted manure is 
simply decomposed organic material that continuously occurs in nature, often without any assistance from mankind. The rate of decomposing depends on type of material, air, moisture, and temperature and soil $\mathrm{pH}$.

Manures improve the texture of both clay and sandy soil; indeed, it is the best additive to make either clay or sandy soil into rich, moisture holding, and loamy soil. They are rich in nitrogen and potassium but have very little $\mathrm{Pi}$. Yet, the availability of soil $\mathrm{Pi}$ is enhanced due to chelating polyvalent cations by organic acids and other decay products. In addition, organic materials are rich substrates for propagation of beneficial microorganisms (see below). However, poorly available, being costly and the unbalanced levels of elements in manures have hindered the effectiveness and wide usage. In addition, these still need microbial activity to release the elements.

\subsection{The use of Pi solubilizing microorganism}

Pi solubilizing microorganisms (PSMs) are, as named, a group of soil fungi and bacteria involved in solubilization and mineralization of soil $\mathrm{P}$ from inorganic and organic pools as an integral part of the P cycle. In soil, Pi solubilizing bacteria out-number fungi with the same activity by $2-150$ folds [135]. The majority of the PSMs solubilize Ca-P complexes in alkaline soils and only a few can solubilize Fe-P and Al-P in acidic soils. Nevertheless, PSMs can become effective in the latter soils when supplemented with PR.

The principle mechanism for Pi solubilization is the secretion of organic acids and APases that play major role in the mineralization of both inorganic and organic Pi compounds in surrounding soil. Several mechanisms like lowering of $\mathrm{pH}$ by acidulation, ion chelating, or ion exchange reactions as well as enzymatic activities in the growth environment have also been proposed to play a role in Pi solubilization by PSMs [91,126,136,137].

Through receiving energetic carbon sources from plant, PSMs facilitate the uptake of Pi and also other nutrients such as zinc, molybdenum, copper and iron. Fungi have been reported to possess greater ability to solubilize rock Pi than bacteria, though they perform better in acidic soil conditions. Species of Aspergillus, Penicillium, Curvularia and yeast have been widely reported to solubiliz various forms of inorganic phosphates [137]. Another mechanism which indirectly leads to increased Pi acquisition by plants is the production of phytohormones (mainly auxins) by rhizobacteria that stimulate root growth [138-139]. Therefore, it makes more sense to name such bacteria as plant growth promoting rhizobacteris (PGPR) [140].

Among the soil Pi solubilizing bacteria communities, Pseudomonas putida, P. strata, Bacillus sircalmous and Pantoa agglomeranse could be referred to as the most important strains [91]. The positive effect of Pseudomonas inoculation on plant growth has been reported in many field trials [126]. The role of Pi solubilizing bacteria and their potential capacity to restore Pi cycle processes in plant-soil system cannot be ignored [138].

Symbiotic relationship between mycorrhizal fungi and plants exists in almost all ecosystems [141]. Fungi species spread around their mycelium acquiring Pi from longer distances which 
is then passed to plants in exchange for carbon compounds [142]. Nevertheless, limitations in mass production and restriction of this relationship to certain plant types have been unsolved issues for wide utilizations so far.

\subsection{Plant species with high Pi efficiency}

Genotypic variations for tolerance to Pi deficiency has been demonstrated for many food crops [143] which provide sources for developing cultivars superior in Pi acquisition and higher yield particularly in deficient conditions through plant breeding [144]. Pi-efficient plants are defined as plants which could produce higher yields per unit of applied or absorbed nutrient compared to other plants grown under similar agroecological conditions [145]. Screening for plant species or genotypes with increased Pi absorption involves criteria such as: (i) greater root growth and, thus, extended soil exploration; (ii) the exuding of proton and organic acids that increase the solubility of $\mathrm{Pi}$ by decreasing $\mathrm{pH}$ and/or chelating; and (iii) the secretions of elevated levels of APase enzymes that break down organic Pi [146].

Most modern crop cultivars have been selected through conventional breeding approaches for better adaptation to deficient soil Pi by looking at root architectural traits which allow for more Pi acquisition from soil surface zone [147]. However, conventional plant breeding including phenotypic selection for improved root systems has proven to be difficult, prone to environmental effects, and time-consuming [148]. As tolerance to low $\mathrm{Pi}$ is a quantitative trait, an appropriate method to dissect its complex polygenic inheritance must be employed through quantitative trait loci (QTL) analysis. A number of QTL have been identified for tolerance mechanisms to low $\mathrm{Pi}$ in various food crops [149]. Molecular markers linked to the target traits are needed to be used for selection in the breeding process.

\subsection{Genetic engineering for Pi acquisition and utilization}

Researches on the molecular and physiological basis of Pi uptake, translocation, and internal utilization facilitate the design and generation of transgenic plants with enhanced $\mathrm{Pi}$ efficiency. For instance, over-expression of a Pi transporter gene in tobacco cell cultures resulted in an increased rate of Pi uptake when cells were grown under Pi limited conditions [47]. Several attempts have been made to improve soil Pi solubilization and acquisition processes in food crops through engineering of genes with bacterial, fungal or plant origins. Increasing knowledge on regulatory and signaling mechanisms involved in Pi acquisition might identify new useful genes. It is assumed that a combined overexpression of Pitransporter and dissolving encoding genes might result in synergistic effects [150].

An overview of reported transgenic crop plants is given in Table 4. Generating plants with an enhanced metabolical Pi uptake capacity were attempted by engineered tobacco plants to produce more organic acids, specifically citrate [150]. The promising result was that these transgenic plants yielded more leaf and fruit biomass than controls when grown under Pilimited conditions [151]. Many studies reported transgenic plants with overexpression of phytase in various food crops. Phytases are exuded into the rhizosphere and are able to 
hydrolyze phytates which constitutes up to $50 \%$ of the total organic $\mathrm{Pi}$ in soil [8]. Overexpression of phytase in potato, clover, soybean and tobacco resulted in increased $\mathrm{Pi}$ acquisition and content. These results point to possible manipulation of biochemical pathways that increase the ability of the plant to release organic acids or enzymes that improve Pi acquisition from soils.

\subsection{Mutagenesis}

Several mutant genes have been successfully introduced into commercial crop varieties that significantly enhance the nutritional value of crops. Mutants of barley, wheat, rice and soybean with low phytic acid have been released and can reduce both Pi pollution and increase bioavailability of $\mathrm{Pi}$ and micronutrient minerals in cereals and legumes [164]. A major QTL pup1, on chromosome 12 effective on Pi uptake from Pi-deficient soils was fine-mapped in rice. Liu and colleagues [165] demonstrated that chromosome $1 \mathrm{R}$ and $7 R$ of rye might carry genes responsible for tolerance to Pi starvation stress, while $5 R$ carry unfavorable genes regarding Pi starvation tolerance.

\begin{tabular}{|c|c|c|c|c|}
\hline Gene Name & Gene source & $\begin{array}{l}\text { Transformed } \\
\text { crop species }\end{array}$ & $\begin{array}{l}\text { Main effect under P } \\
\text { deficiency }\end{array}$ & Reference \\
\hline Secretary phytase & synthetic & Potato & $\begin{array}{l}\text { Increased P content and } \\
\text { biomass if phytate } \\
\text { available }\end{array}$ & [152] \\
\hline Phytase & $\begin{array}{l}\text { Aspergillus } \\
\quad \text { niger }\end{array}$ & Clover & $\begin{array}{l}\text { Increased P uptake if } \\
\text { phytate available }\end{array}$ & [17] \\
\hline Phytase & A. niger & Clover & $\begin{array}{l}\text { Increased P uptake in } \\
\text { sterile media (phytate } \\
\text { available)-no effect in } \\
\text { soil }\end{array}$ & [153] \\
\hline Phytase & A. niger & Tobacco & $\begin{array}{l}\text { Increased P uptake if } \\
\text { phytate available }\end{array}$ & {$[154]$} \\
\hline$\beta$-Propeller phytase & $\begin{array}{l}\text { Bacillus } \\
\text { subtilis }\end{array}$ & Tobacco & $\begin{array}{l}\text { Increased P content and } \\
\text { biomass }\end{array}$ & [155] \\
\hline Phytase & A. ficuum & Soybean & $\begin{array}{l}\text { Increased phytase } \\
\text { activity and P content } \\
\text { in root exudates }\end{array}$ & [156] \\
\hline $\begin{array}{l}\text { Phytase and acid } \\
\text { phosphatase }\end{array}$ & $\begin{array}{l}\text { Medicago } \\
\text { truncatula }\end{array}$ & Clover & $\begin{array}{l}\text { Increased } \mathrm{P} \text { content and } \\
\text { biomass }\end{array}$ & [157] \\
\hline Acid phosphatase & white lupin & Tobacco & $\begin{array}{l}\text { Increased P uptake and } \\
\text { growth }\end{array}$ & [158] \\
\hline $\begin{array}{l}\text { Purple acid } \\
\text { Phosphatase } 18\end{array}$ & A. thaliana & $\begin{array}{l}\text { Arabidopsis } \\
\text { thaliana and } \\
\text { tobacco }\end{array}$ & $\begin{array}{l}\text { Increased } \mathrm{P} \text { uptake, } \mathrm{P} \\
\text { content and biomass }\end{array}$ & [158] \\
\hline
\end{tabular}




\begin{tabular}{lcc|cc}
\hline Gene Name & Gene source & $\begin{array}{l}\text { Transformed } \\
\text { crop species }\end{array}$ & $\begin{array}{l}\text { Main effect under P } \\
\text { deficiency }\end{array}$ & Reference \\
\hline $\begin{array}{l}\text { High-affinity P- } \\
\text { transporter }\end{array}$ & Barley & Barley & No effect & {$[43]$} \\
$\begin{array}{l}\text { High-affinity P- } \\
\text { transporter }\end{array}$ & tobacco & Rice & Increased P uptake & {$[160]$} \\
$\begin{array}{l}\text { Malate } \\
\text { dehydrogenase } \\
\text { (MDH) } \\
\text { overexpression }\end{array}$ & Alfalfa & $\begin{array}{l}\text { Increased organic acid } \\
\text { exudation }\end{array}$ & {$[161]$} \\
$\begin{array}{l}\text { Phosphoenolpyruvat } \\
\text { e carboxylase (PFPC) } \\
\text { overexpression }\end{array}$ & A. thaliana & Rice and tomato & $\begin{array}{l}\text { More robust roots, } \\
\text { higher shoot mass, } \\
\text { Type I H+ } \\
\text {-pyrophosphatase }\end{array}$ \\
$\begin{array}{l}\text { AVP1 } \\
\text { Aluminum resistance } \\
\text { gene }\end{array}$ & wheat & Alfalfa & $\begin{array}{l}\text { No increase in organic } \\
\text { acid exudation }\end{array}$ & {$[161]$} \\
\hline
\end{tabular}

Table 4. An overview of some reported genetic engineering in crop species

\section{Conclusion}

Chemical fertilizers have played a significant role in the Green Revolution to have improved yield and to combat hunger to some extent [166]. However, poorly managed consumption of resources and even poor applications of Pi fertilizers and side products have endangered our environment. These factors have encouraged researchers to seek bio-friendly, economically feasible, and replaceable sources of Pi before the world consumption rate will rich to a no-return point. In order to secure agricultural sustainability through reduction in Pi fertilizer overuse, plant and soil scientists have tried to address solutions for retrieval of Pi from P-compounds in the rhizosphere, soils in the a close proximity of root. Two major approaches in the current research and technology world are:

1. To bioengineer Pi efficient transgenic crops expressing enzymes such as phosphatases. This solution has been highly approached by many scientists (for a review see [84]). However, transgenic plants were found to be affected by the non-desired traits or epitasis among numerous APase-encoding genes. Even if a transgenic plant acquire release permission, still we are limited to use a lines variety of the transgenic crop.

2. To bioengineer rhizosphere by the use of beneficial microorganisms as biofertilizers involved in solubilization of $\mathrm{Pi}$ in the soil, namely "Pi biofertilizers". This approach is advantageous as Pi biofertilizers could be applied to wide range of crops and their varieties as desired. Besides, signaling of sufficient availability of Pi in the rhizosphere would regulate the expression and secretion of organic acids and/or APase enzymes by 
the microorganisms. Such an elegant smart mechanism leads to natural growth and development of plants.

To this end, years of researches on chemical, organic and biological Pi fertilizers have shown that none can replace the other. Practically, achieved higher yield and quality with combinations of all three in certain proportions address a call for precise farming with integrative plant nutrition programs prescribed based on crop and soil requirements.

\section{Author details}

Mohammad Ali Malboobi*, Ali Samaeian, and Tahmineh Lohrasebi

Department of Plant Biotechnology, National Institute of Genetic Engineering and Biotechnology,

Tehran, I.R. Iran

Mohammad Sadegh Sabet

Department of Plant Breeding and Biotechnology, Faculty of Agriculture, Tarbiat Modares

University, Tehran, I.R. Iran

\section{Acknowledgement}

We would like to express our appreciation to those who contributed to data compilation and sharing through Phosphate Knowledge Center (http://www. GreenPi.info), FAO, IFDC, IMPHOS and Global Phosphate Research Initiatives (http://www.phosphorusfutures.net).

\section{References}

[1] Vance CP. Symbiotic Nitrogen Fixation and Phosphorus Acquisition. Plant Nutrition in a World of Declining Renewable Resources. Plant Physiol; 2001. 127(2): 390-7.

[2] Bieleski RL. Phosphate Pools, Phosphate Transport and Phosphate Availability. Annual Review of Plant Physiology; 1973. 24: 225-252. doi: 10.1146/annurev.pp. 24.060173.001301

[3] Hinsinger P. Bioavailability of Soil Inorganic P in the Rhizosphere as Affected by RootInduced Chemical Changes: A Review. Plant Soil; 2001. 237: 173-195.

[4] Conyers MK., Moody PW. A Conceptual Framework for Improving the P Efficiency of Organic Farming without Inputs of Soluble P Fertiliser. Crop \& Pasture Science; 2009. 60: 100-104.

[5] Harrison AF. Soil Organic Phosphorus: A Review of World Literature. CAB International: Wallingford, UK; 1987.

[6] Sanyal SK., De Datta SK. Chemistry of Phosphorus Transformations in Soil. Advances in Soil Science; 1991. 16: 1-120.

[7] DalalR C. Soil Organic Phosphorus. Advances in Agronomy; 1977. 29: 85-117.

\footnotetext{
${ }^{*}$ Corresponding Author
} 
[8] Anderson, G. Assessing Organic Phosphorus in Soil. In: Khasawneh FE., Sample EC., Kamprath EJ. (Eds.), The Role of Phosphorus in Agriculture. American Society of Agronomy, Madison, WI, USA; 1980. p411-431.

[9] Tate KR. The Biological Transformation of P in Soil. Plant and Soil; 1984. 76: 245-256. doi: 10.1007/BF02205584.

[10] Stewart JWB., Tiessen H. Dynamics of Soil Organic Phosphorus. Biogeochemistry; 1987. 4: 41-60. doi: 10.1007/BF02187361.

[11] Hedley MJ., Mortvedt JJ., Bolan NS., Syers JK. Phosphorus Fertility Management in Agroecosystems. In 'Phosphorus in the Global Environment: Transfers, Cycles and Management'. (Ed. H Tiessen) (Wiley and Sons: London); 1995. p59-92.

[12] Magid J., Tiessen H., CondronLM. Dynamics of Organic Phosphorus in Soils under Natural and Agricultural Ecosystems. In 'Humic Substances in Terrestrial Ecosystems'. (Ed. A Piccolo) (Elsevier Science: Amsterdam); 1996. p429-466.

[13] Frossard E., Condron LM., Oberson A., Sinaj S., Fardeau JC. Processes Governing Phosphorus Availability in Temperate Soils. Journal of Environmental Quality; 2000. 29: 15-23.

[14] Manske GGB., Ortiz-Monasterio JI., Van Grinkel M., Rajaram S., Molina E., Vick PLG. Traits Associated with Improved P-uptake Efficiency in CIMMYT's Semidwarf Spring Bread Wheat Grown on an Acid Andisol in Mexico. Plant and Soil. 2000. 221: 189-204. doi: 10.1023/A:1004727201568

[15] Simpson JR., Pinkerton A. Fluctuations in Soil Moisture, and Plant Uptake of Surface Applied Phosphate. Nutrient Cycling in Agroecosystems; 1989. 20(2): 101-108, DOI: 10.1007/BF01055434

[16] Tiessen H. Phosphorus in the Global Environment. In White PJ., Hammond JP., eds, Ecophysiology of Plant-Phosphorus Interactions. Springer, New York; 2008. p1-8.

[17] Richardson AE . Regulating the Phosphorus Nutrition of Plants: Molecular Biology Meeting Agronomic Needs. Plant and Soil; 2009. 322(1-2): 17-24, DOI: 10.1007/s11104009-0071-5.

[18] Richardson AE., Hocking PJ., Simpson RJ., George TS. Plant Mechanisms to Optimise Access to Soil Phosphorus. Crop \& Pasture Science; 2009. 60: 124-143.

[19] Barber, SA, Soil Nutrient Bioavailability. A Mechanistic Approach. Wiley-Interscience Publication, New York. 1984

[20] Gahoonia TS., Nielsen NE. Variation in Root Hairs of Barley Cultivars Doubled Phosphorus Uptake from Soil. Euphytica; 1997. 98(3): 177-182.

[21] Tinker, PB., Nye, PH. Solute Movement in the Rhizosphere. Oxford University Press, Oxford. 2000.

[22] de Willigan P., van Noordwijk M. Roots, plant production and nutrient use efficiency. PhD Thesis, Agricultural University Wageningen, The Netherlands. 1987.

[23] Raghothama KG. Phosphate Acquisition. Annu Rev Plant Physiol; 1999. 50: 665-693.

[24] Raghothama KG. Phosphate Transport and Signalling. Current Opinion in Plant Biology; 2000. 3:182-187.

[25] Mimura T. Regulation of Phosphate Transport and Homeostasis in Plants. Int Rev Cytol; 1999. 191: 149-200. 
[26] Schachtman DP., Reid RJ., Ayling SM. Phosphorus Uptake by Plants: from Soil to Cell. Plant Physiol; 1998. 116: 447-453.

[27] Daram P., Brunner S., Amrhein N., Bucher M. Functional Analysis and Cell-Specific Expression of a Phosphate Transporter from Tomato. Planta; 1998. 206: 225-233.

[28] Smith SE., Read DJ. Mycorrhizal Symbiosis. Academic Press, Cambridge; 1997.

[29] Karandashov V., Nagy R., Wegmuller S., Amrhein N., Bucher M. Evolutionary Conservation of a Phosphate o`Transporter in the Arbuscular Mycorrhizal Symbiosis. Proc. Natl. Acad. Sci. USA; 2004. 101: 6285-6290.

[30] Harrison MJ. Signaling in the Arbuscular Mycorrhizal Symbiosis. Annu. Rev. Microbiol.; 2005. 59: 19-42.

[31] Bucher M. Functional Biology of Plant Phosphate Uptake at Root and Mycorrhiza Interfaces. New Phytol; 2007. 173: 11-26.

[32] Rausch C, Bucher M. Molecular Mechanisms of Phosphate Transport in Plants. Planta; 2002. 216(1): 23-37, DOI: 10.1007/s00425-002-0921-3

[33] Picault N., Hodges M., Palmieri L., Palmieri F. The Growing Family of Mitochondrial Carriers in Arabidopsis. Trends in Plant Science; 2004. 9: 138-146.

[34] Knappe S., Flugge UI., Fischer K. Analysis of the Plastidic Phosphate Translocator Gene Family in Arabidopsis and Identification of New Phosphate Translocator-Homologous Transporters, Classified by Their Putative Substrate-Binding Site. Plant Physiology; 2003. 131: 1178-1190.

[35] Grunwald U., Guo W., Fischer K., Isayenkov S., Ludwig-Müller J., Hause B., Yan X., Küster H., Franken P. Overlapping Expression Patterns And Differential Transcript Levels Of Phosphate Transporter Genes In Arbuscular Mycorrhizal, Pi-Fertilised And Phytohormone-Treated Medicago Truncatula Roots. Planta, 2009. 229(5): 1023-1034, DOI: $10.1007 / \mathrm{s} 00425-008-0877-\mathrm{z}$

[36] Leggewie G., Wilmitzer L., Riesmeier JW. Two cDNAs From Potato Are Able to Complement a Phosphate Uptake-deficient Yeast Mutant: Identification of Phosphate Transporters from Higher Plants. Plant Cell; 1997. 9: 381.

[37] Okumura S., Mitsukawa N., Shirano Y. Shibata D. Phosphate Transporter Gene Family of Arabidopsis thaliana. DNA Res; 1998. 5: 261-269.

[38] Liu C., Muchal US., Mucatira U., Kononowicz AK. Raghothama KG. Tomato Phosphate Transporter Genes Are Differentially Regulated in Plant Tissues by Phosphorus. Plant Physiol.; 1998a. 116: 91-99.

[39] Liu H., Trieu AT., Blaylock LA. Harrison MJ. Cloning and Characterisation of Two Phosphate Transporters from Medicago Truncatular Roots: Regulation in Response to Phosphate and to Colonization by Arbuscular Mycorrhizal (AM) Fungi. Mol. Plant Microbe Interact.; 1998b. 11: 14- 22.

[40] Paszkowski U., Kroken S., Roux C., Briggs SP. Rice Phosphate Transporters Include an Evolutionarily Divergent Gene Specifically Activated in Arbuscular Mycorrhizal Symbiosis. Proc Natl Acad Sci USA; 2002. 99: 13324-13329.

[41] Nagy R., Vasconcelos M., Zhao S., McElver J., Bruce W., Amrhein N., Raghothama K. E Bucher M. Differential Regulation of Five Pht1 Phosphate Transporters from Maize (Zea mays L.). Plant Biology; 2006. 8: 186-197. 
[42] Mudge SR., Rae AL., Diatloff E., Smith FW. Expression Analysis Suggests Novel Roles for Members of the Pht1 Family of Phosphate Transporters in Arabidopsis. Plant J.; 2002. 31: 341-353.

[43] Rae AL., Jarmey JM., Mudge SR. Smith FW. Overexpression of a High-affinity Phosphate Transporter in Transgenic Barley Plants Does not Enhance Phosphate Uptake Rates. Funct. Plant Biol.; 2004. 31(2): 141-148.

[44] Glassop D., Smith SE., Smith F W. Cereal Phosphate Transporters Associated with the Mycorrhizal Pathway of Phosphate Uptake into Roots. Planta; 2005. 222: 688-698.

[45] Balestrini R., Gomez-Ariza J., Lanfranco L., Bonfante P. Laser Microdissection Reveals that Transcripts for Five Plant and One Fungal Phosphate Transporter Genes are Contemporaneously Present in Arbusculated Cells. Mol Plant Microbe Interact; 2007. 20: 1055-1062.

[46] Wu Z., Zhao J., Gao R., Hu G., Gai J., Xu G., Xing H. Molecular Cloning, Characterization and Expression Analysis of Two Members of the Pht1 Family of Phosphate Transporters in Glycine max. PLoS ONE; 2011. 6(6): e19752. doi:10.1371/journal.pone.0019752.

[47] Mitsukawa N., Okumura S., Shirano Y., Sato S., Kato T., Harashima S., Shibata D. Overexpression of an Arabidopsis thaliana High-affinity Phosphate Transporter Gene in Tobacco Cultured Cells Enhances Cell Growth Under Phosphate-limited Conditions. Proc Natl Acad Sci USA; 1997. 94: 7098-7102.

[48] Shin H., Shin HS., Dewbre GR., Harrison MJ. Phosphate Transport in Arabidopsis: Pht1;1 and Pht1;4 Play a Major Role in Phosphate Acquisition from Both Low- and High-phosphate Environments. Plant J.; 2004. 39: 629-642.

[49] Marschner H. Mineral Nutrition of Higher Plants. Academic Press, San Diego, CA; 1995.

[50] Hamburger D., Rezzonico E., Petetot JMC., Somerville C. Poirier Y. Identification and Characterization of the Arabidopsis PHO1 Gene Involved in Phosphate Loading to the Xylem. Plant Cell; 2002. 14: 889-902.

[51] Jeschke W., Kirkby E., Peuke A., Pate J., Hartung W. Effects of P EFFICIENCY on Assimilation and Transport of Nitrate and Phosphate in Intact Plants of Castor Bean (Ricinus communis L.). J Exp Bot; 1997. 48: 75-91.

[52] Versaw WK, Harrisons MJ. A Chloroplast Phosphate Transporter, PHT2;1, Influences Allocation of Phosphate within the Plant and Phosphate Starvation Responses. Plant Cell; 2002. 14: 1751-1766.

[53] Williamson LC., Ribrioux SPCP., Fitter AH., Leyser HMO. Phosphate availability regulates root system architecture in Arabidopsis. Plant Physiol.; 2001. 29: 875-890.

[54] Thaler P, Pages L. Modeling the Influence of Assimilate Availability on Root Growth and Architecture. Plant Soil; 1998. 201: 307-320.

[55] Fitter A, Williamson L, Linkohr B, Leyser O. Root System Architecture Determines Fitness in an Arabidopsis Mutant in Competition for Immobile Phosphate Ions but not for Nitrate Ions. Proc. Biol. Sci.; 2002. 269: 2017-2022. 
[56] Basirat M., Malboobi MA., Mousavi A., Asgharzadeh A., Samavat S. Effects of Phosphorous Supply on Growth, Phosphate Distribution and Expression of Transporter Genes in Tomato Plants. AJCS; 2011. 5(5): 537-543.

[57] Lynch JP., Brown KM. Topsoil Foraging - An Architectural Adaptation Of Plants To Low Phosphorus. Plant and Soil; 2001. 237(2): 225-237, DOI: 10.1023/A:1013324727040

[58] Neumann G., Martinoia E. Cluster Roots: An Underground Adaptation for Survival in Extreme Environments. Trends Plant Sci.; 2002. 7: 162-167.

[59] Lamont BB. Structure, Ecology and Physiology of Root Clusters: A Review. Plant and Soil; 2003. 248: 1-19.

[60] Shane MW., Lambers H. Cluster Roots: A Curiosity in Context. Plant and Soil; 2005. 274: 101-125.

[61] Lambers H., Shane MW. Role of Root Clusters in Phosphorus Acquisition and Increasing Biological Diversity in Agriculture. Wageningen UR Frontis Series; 2007. 21: 235.

[62] Peret B., Péret B., Svistoonoff S., Laplaze L.When Plants Socialize: Symbioses and Root Development. Annu. Plant Rev.; 2009. 37: 209-238.

[63] Smith SE., Smith FA. Roles of Arbuscular Mycorrhizas in Plant Nutrition and Growth: New Paradigms from Cellular to Ecosystem Scales. Annu. Rev. Plant Biol.; 2011. 62: 16.1-16.24.

[64] Forde B., Lorenzo H. The Nutritional Control of Root Development. Plant and Soil; 2001. 232: 51-68.

[65] Chevalier F. Pata M., Narcy P., Doumas P., Rossignol M. Effects of Phosphate Availability on the Root System Architecture: large-Scale Analysis of the Natural Variation between Arabidopsis Accessions. Plant Cell Environment; 2003. 26:1839-1850.

[66] Sánchez-Calderón L., López-Bucio J., Chacón-López A., Gutiérrez-Ortega A., Hernández-Abreu E., Herrera-Estrella L. Characterization of Low Phosphorus Insensitive Mutants Reveals a Crosstalk between Low Phosphorus Induced Determinate Root Development and the Activation of Genes Involved in the Adaptation of Arabidopsis to Phosphorus Deficiency. Plant Physiol.; 2006. 140: 879-889.

[67] Wu P., Ma L., Hou X., Wang M., Wu Y., Liu F., Deng X.W. Phosphate Starvation Triggers Distinct Alterations of Genome Expression in Arabidopsis Roots and Leaves. Plant Physiol.; 2003. 132: 1260-1271.

[68] Misson J., Raghothama KG., Jain A.,et al. A Genome-wide Transcriptional Analysis Using Arabidopsis thaliana Affymetrix Gene Chips Determined Plant Responses to Phosphate Deprivation. Proc. Natl. Acad. Sci. U.S.A.; 2005. 102: 11934-11939.

[69] Morcuende R. Bari R., Gibon Y., Zheng W., Pant BD., Blasing O., Usadel B.,Czechowski T., Udvardi MK., Stitt M., Schible W. Genome-wide Reprogramming of Metabolism and Regulatory Networks of Arabidopsis in Response to Phosphorus. Plant Cell Environ.; 2007. 30: 85-112.

[70] Thibaud M.C., Arrighi J.F., Bayle V., Chiarenza S., Creff A., Bustos R., Paz-Ares J., Poirier Y., Nussaume L. Dissection of Local and Systemic Transcriptional Responses to Phosphate Starvation in Arabidopsis. Plant J.; 2010. 64: 775-789. 
[71] Bozzo GG., Raghothama KG., Plaxton WC. Structural and Kinetic Properties of a Novel Purple Acid Phosphatase from Phosphate-starved Tomato (Lycopersicon esculentum) Cell Cultures. Biochem J.; 2004a. 377: 419-428

[72] Veljanovski V., Vanderbeld B., Knowles VL., Snedden WA., Plaxton WC. Biochemical and Molecular Characterization of AtPAP26, A Vacuolar Purple Acid Phosphatase Upregulated in Phosphate-deprived Arabidopsis Suspension Cells and Seedlings. Plant Physiol; 2006. 142: 1282-1293.

[73] Tran HT., Hurley BA. Plaxton WC. Feeding Hungry Plants: the Role of Purple Acid Phosphatases in Phosphate Nutrition. Plant Science; 2010a. 179: 14-27.

[74] Fang ZY., Shao C., Meng YJ., Wu P., Chen M. Phosphate Signaling in Arabidopsis and Oryza Sativa. Plant Sci.; 2009. 176: 170-180.

[75] Vance CP., Uhde-Stone C. Allan DL. P Acquisition and Use: Critical Adaptations by Plant for Securing a Non-renewable Resources. New Physiologist; 2003. 157:427-447.

[76] Jiang CF., Gao XH., Liao LL., Harberd NP., Fu XD. Phosphate starvation root architecture and anthocyanin accumulation responses are modulated by the gibberellinDELLA signaling pathway in Arabidopsis. Plant Physiol. 2007; 145, 1460-1470.

[77] Lin WY., Lin SI., Chiou TJ. Molecular Regulators of Phosphate Homeostasis in Plants. J. Exp Bot; 2009. 60: 1427-1438.

[78] Yu B., Xu CC., Benning C. Arabidopsis Disrupted in SQD2 Encoding Sulfolipid Synthase is Impaired in Phosphate-limited Growth. Proc Natl Acad Sci USA; 2002. 99: 5732-5737.

[79] Li M., Qin C., Welti R., Wang X. Double Knockouts of Phospholipases Dz1 and Dz2 in Arabidopsis Affect Root Elongation During Phosphate Limited Growth but Do not Affect Root Hair Patterning. Physiol Plant; 2006. 140:761-770.

[80] Gaude N., Nakamura Y., Scheible WR., Ohta H., Dormann P. Phospholipase C5 (NPC5) is Involved in Galactolipid Accumulation During Phosphate Limitation in Leaves of Arabidopsis. Plant J.; 2008. 56: 28-39.

[81] Duff SMG., Moorhead GB., Lefebvre DD., Plaxton WC. Phosphate Starvation Inducible "bypasses" of Adenylate and Phosphate Dependent Glycolytic Enzymes in Brassica Nigra Suspension Cells. Plant Physiol; 1989. 90:1275-1278.

[82] Plaxton WC., Podesta FE. The Functional Organization and Control of Plant Respiration. Crit Rev Plant Sci; 2006. 25: 159-198.

[83] Gregory AL., Hurley BA., Tran HT., Valentine AJ., She YM., Knowles VL., Plaxton WC. In Vivo Regulatory Phosphorylation of the Phosphoenolpyruvate Carboxylase AtPPC1 in Phosphate-starved Arabidopsis thaliana. Biochem J.; 2009. 420: 57-65.

[84] Tran HT., Qian W., Hurley BA., She YM., Wang D., Plaxton WC. Biochemical and Molecular Characterization of AtPAP12 and AtPAP26: The Predominant Purple Acid Phosphatase Isozymes Secreted by Phosphate-starved Arabidopsis thaliana. Plant Cell Environ; 2010b. 33: 1789-1803.

[85] Plaxton WC., Tran HT. Metabolic Adaptations of Phosphate-Starved Plants. Plant Physiology; 2011. 20(156): 1006-1015.

[86] Ticconi CA., Abel S. Short on Phosphate: Plant Surveillance and Countermeasures. Trends Plant Sci; 2004. 9: 548-555. 
[87] Nilsson L., Muller R., Nielsen TH. Dissecting the Plant Transcriptome and the Regulatory Responses to Phosphate Deprivation. Physiol Plant; 2010. 139: 129-143.

[88] Liang C., Tian J., Lam HM., Lim BL., Yan X., Liao H. Biochemical and Molecular Characterization of PvPAP3, A Novel Purple Acid Phosphatase Isolated from Common Bean Enhancing Extracellular ATP Utilization. Plant Physiol; 2010. 152: 854-865.

[89] Tarafdar JC., Claasen N. Organic Phosphorus Compounds as a Phosphorus Source for Higher Plants through the Activity Of Phosphatases Produced By Plant Roots and Microorganisms. Biol. Fert. Soils; 1988. 5: 308-312.

[90] Tarafdar JC., Rao AV., Kumar P. Role of Phosphate Producing Fungi on the Growth and Nutrition of Clusterbean (Cyamopsis tetragonoloba (L.) Taub.). Journal of Arid Environments; 1995. 29(3): 31-337, ISSN 0140-1963.

[91] Malboobi MA., Owlia P., Behbahani M., Sarokhani E., Moradi S., Yakhchali B., Deljou A., Morabbi K. Solubilization of Organic and Inorganic Phosphates by Three Efficient Soil Bacterial Isolates. World Journal of Microbiology Biotechnology; 2009a. 25: 14711477.

[92] Duff S MG., Sarath G., Plaxton WC. The Role of Acid Phosphatase In Plant Phosphorus Metabolism. Physiol. Plant.; 1994. 90: 791-800.

[93] Yan F., Zhu YY., Muller C., Zorb C., Schubert S. Adaptation of H+-pumping and Plasma Membrane H+ ATPase Activity in Proteoid Roots of white Lupin under Phosphate Deficiency. Plant Physiol; 2002. 129: 50-63.

[94] Diatloff E., Roberts M., Sanders D., Roberts SK. Characterization of Anion Channels in the Plasma Membrane of Arabidopsis Epidermal Root Cells and the Identification of a Citrate-permeable Channel Induced by Phosphate Starvation. Plant Physiol; 2004. 136: 4136-4149.

[95] Hammond JP., Bennett MJ., Bowen HC., Broadley MR., Eastwood DC., May ST., Rahn C., Swarup R., Woolaway KE., White PJ. Changes in Gene Expression in Arabidopsis Shoots during Phosphate Starvation and the Potential for Developing Smart Plants. Plant Physiol; 2003. 132: 578-586.

[96] Uhde-Stone C., Zinn KE., Ramirez-Yanez M., Li A., Vance CP., Allan DL. Nylon Filter Arrays Reveal Differential Gene Expression in Proteoid Roots of White Lupin in Response to Phosphorus Deficiency. Plant Physiol.; 2003. 131: 1064-1079.

[97] Wasaki J., Yonetani R., Kuroda S., Shinano T., Yazaki J., Fujii F., Shimbo K., Yamamoto K., Sakata K., Sasaki T., et al. Transcriptomic Analysis of Metabolic Changes by Phosphorus Stress in Rice Plant Roots. Plant, Cell and Environment; 2003b. 26: 15151523.

[98] Wasaki J., Shinano T., Onishi K., Yonetani R., Yazaki J., Fujii F., Shimbo K., Ishikawa M., Shimatani Z., Nagata Y., et al. Transcriptomic Analysis Indicates Putative Metabolic Changes Caused by Manipulation of Phosphorus Availability in Rice Leaves. J Exp Bot; 2006. 57: 2049-2059.

[99] Graham MA., Ramirez M., Valdes-Lopez O., Lara M., Tesfaye M., Vance CP., Hernandez G. Identification of Candidate Phosphorus Stress Induced Genes in Phaseolus Vulgaris through Clustering Analysis Across Several Plant Species. Funct Plant Biol; 2006. 33: 789-797. 
[100] Wang X., Yi K., Tao Y., Wang F.,Wu Z., Jiang D., Chen X., Zhu L., Wu P. Cytokinin Represses Phosphate-starvation Response through Increasing of Intracellular Phosphate Level. Plant Cell Environ.; 2006. 29: 1924-1935.

[101] Hammond JP., Philip J. White Sugar Signalling in Root Responses to Low Phosphorus Availability. Plant Physiology; 2011. 156: 1033-1040.

[102] Muller R., Morant M., Jarmer H., Nilsson L., Nielsen TH. Genome-wide Analysis of the Arabidopsis Leaf Transcriptome Reveals Interaction of Phosphate and Sugar Metabolism. Plant Physiol; 2007. 143: 156-171.

[103] Lin SI., Chiang SF., Lin WY., Chen JW., Tseng CY., Wu PC., Chiou TJ. Regulatory Network of MicroRNA399 and PHO2 by Systemic Signalling. Plant Physiol; 2008. 147: 732-746.

[104] Bustos R., Castrillo G., Linhares F., Rubio V., Puga MI., Perez-Perez J., Solano R., Leyva A., Paz-Ares J. A Central Regulatory System Lergely Controls Transcriptional Activation and Repression Responses to Phosphate Starvation in Arabidopsis. PLoS Genet; 2010. 6(9): e1001102. doi:10.1371/journal.pgen.1001102.

[105] Rubio V., Linhares F., Solano R., Martin, AC., Iglesias J., Leyva A., Paz-Ares J. A Conserved MYB Transcription Factor Involved in Phosphate Starvation Signaling both in Vascular Plants and in Unicellular Algae Genes Dev.; 2001. 15;2122-2133.

[106] Hsieh LC., Lin SI., Shih AC., Chen JW., Lin WY., Tseng CY., Li WH., Chiou TJ. Uncovering Small RNA-mediated Responses to Phosphate Deficiency in Arabidopsis by Deep Sequencing. Plant Physiol; 2009. 151: 2120-2132.

[107] Fujii H., Chiou TJ., Lin SI., Aung K., Zhu JK. A miRNA Involved in PhosphateStarvation Response in Arabidopsis. Curr Biol; 2005. 15: 2038-2043.

[108] Pant BD., Musialak-Lange M., Nuc P., May P., Buhtz A., Kehr J., Walther D., Scheible WR. Identification of Nutrient-responsive Arabidopsis and Rapeseed MicroRNAs by Comprehensive Real-time Polymerase Chain Reaction Profiling and Small RNA Sequencing. Plant Physiol; 2009. 150:1541-1555.

[109] Doerner P. Phosphate Starvation Signaling: A Threesome Controls Systemic Pihomeostasis. Curr Opin Plant Biol; 2008. 11: 536-540.

[110] Pant BD., Buhtz A., Kehr J., Scheible WR. MicroRNA399 Is a Long Distance Signal for the Regulation of Plant Phosphate Homeostasis. Plant J.; 2008. 53: 731-738.

[111] Liu C., Muchhal US., Raghothama KG. Differential Expression of TPS11, A Phosphate Starvation-induced Gene in Tomato. Plant Mol Biol; 1997. 33: 867-874.

[112] Burleigh SH., Harrison MJ. A Novel Gene Whose Expression in Medicago Truncatula Roots Is Suppressed in Response to Colonization by Vesicular-arbuscular Mycorrhizal (VAM) Fungi and to Phosphate Nutrition. Plant Mol Biol; 1997. 34: 199-208.

[113] Franco-Zorrilla JM., Valli A., Todesco M., Mateos I., Puga MI., Rubio- Somoza I., Leyva A., Weigel D., Garcia JA., Paz-Ares J. Target Mimicry Provides a New Mechanism for Regulation of MicroRNA Activity. Nat Genet; 2007. 39: 1033-1037.

[114] Zhou J., Jiao F.,Wu Z., Li Y.,Wang X., He X., Zhong W., Wu P. OsPHR2 Is Involved in Phosphate-starvation Signalling and Excessive Phosphate Accumulation in Shoots of Plants. Plant Physiol; 2008. 146: 1673-1686. 
[115] Rouached H., Arpat AB. Poirier Y. Regulation of Phosphate Starvation Responses in Plants: Signaling Players and Cross-Talks. Molecular Plant; 2010. 3(2): 288-299.

[116] Van Straaten P. Rocks for Crops: Agrominerals of Sub-Saharan Africa. ICRAF, Nairobi, Kenya; 2002. p7-24.

[117] Morse D. Phosphate Rocks. US Department of the Interior Bureau of Mines Annual Report; 1992.

[118] Cisse L., Mrabet T. World Phosphate Production: Overview and Prospects; Phosphorus Research Bulletin; 2004. 15: 21-25.

[119] FAO. Current World Fertilizer Trends and Outlook to 2011/12. FAO; 2008. Rome.

[120] FAO. Use of Pi Rocks for Sustainable Agriculture. FAO; 2004. Rome.

[121] FAO. Current World Fertilizer Trends and Outlook to 2015. FAO; 2011. Rome.

[122] IMPHOS. Addressing Environmental Issues Associated with Phosphate. IMPHOS phosphate newsletter; 2009. 26. Available: www.imphos.org (accessed 18 May 2012).

[123] IMPHOS. Phosphate Trent and Outlook. IMPHOS phosphate newsletter; 2007. 25. Available: www.imphos.org (accessed 18 May 2012).

[124] Schipper WJ., Klapwijk A., Potjer B., Rulkens WH., Temmink BG., Kiestra FDG., Lijmbach ACM. Phosphate Recycling in Phosphorous Industry. Phosphorous Research Bulletin; 2004. 15: 47-51.

[125] Ivanova R., Bojinova D., Nedialkova K. Rock Phosphate Solubilisation by Soil Bacteria.J of the University of Chemical Technology and Metallurgy; 2006. 41(3): 297302.

[126] Malboobi MA., Behbahani M., Madani H., Owlia P., Deljou A., Yakhchali B., Moradi M., Hassanabadi H. The Performance of Potent Phosphate Solubilizing Bacteria in Potato Rhizosphere. World Journal of Microbiology Biotechnology; 2009b. 25: 14791484.

[127] Johnston AE., Ehlert PAI., Kueche M., Amar B., Jaggard KW., Morel C. The Effect of Phosphate Fertilizer Management Strategies on Soil Phosphorus Status and Crop Yields in Some European Countries. IMPHOS; 2001.

[128] Havlin JL., Beaton JD., Tisdale SL., Nelson WL. Soil Fertility and Fertilizers: An Introduction to Nutritional Management. New Jersey: Pearson; 2005.

[129] Cordell D., Drangert J-O., White S. The Story of Phosphorus: Global Food Security and Food for Thought. Global Environmental Change; 2009. 19: 292-305.

[130] IFDC, World Phosphate Rock Reserves and Resources, 2010, IFDC report.

[131] Cisse L., Amar B. The Importance of Phosphatic Fertilizer for Increased Crop Production in Developing Countries. In: Proceedings of the A6th International Annual conference, Cairo, Egypt; 2000.

[132] Stewart W., Hammond L. Kauwenbergh SJV. Phosphorus as a Natural Resource. Phosphorus: Agriculture and the Environment, Agronomy Mono-graph No.46. Madison, American Society of Agronomy. Crop Science Society of America. Soil Science Society of America; 2005.

[133] EPA. Fertilizer and Fertilizer Production Wastes. 2012;

http://www.epa.gov/radiation/tenorm/fertilizer.html (accessed 18 May 2012). 
[134] Turner BL., Frossard E. Baldwin DS. Organic Phosphorus in the Environment. CAB International, Wallingford, UK; 2005. p 432.

[135] Gyaneshwar P., Kumar GN., Parekh LJ., Poole PS. Role of Soil Microorganisms in Improving P Nutrition of Plants. Plant and Soil; 2002. 245: 83-93.

[136] Yadav KS., Dadarwal KR. In Biotechnological Approaches in Soil Microorganisms for Sustainable Crop Production (ed. Dadarwal K.R), Scientific Publishers. Jodhpur; 1997. p293-308.

[137] Kang SC., Ha CG., Lee TG. Maheshwari DK. Solubilization of Insoluble Inorganic Phosphates by a Soil-Inhabiting Fungus Fomitopsis sp. PS 102. Current Science; 2002. 82(4): 439-442.

[138] Subbarao WS. Pi Solubilizing Microorganism in: Biofertilizer in Agriculture; 1988. p133-142.

[139] Arpana N., Kumar SD., Prasad TN. Effect of Seed Inoculation, Fertility and Irrigation on Uptake of Major Nutrients and Soil Fertility Status after Harvest of Late Sown Lentil. Journal of Applied Biology; 2002. 12(1/2): 23-26.

[140] Hodge A., Berta G., Doussan C., Merchan F., Crespi M. Plant Root Growth, Architecture and Function. Plant Soil; 2009. 321: 153-187.

[141] Mehrvarz S., Chaichi MR. Effect of Pi Solubilizing Microorganisms and Phosphorus Chemical Fertilizer on Forage and Grain Quality of Barely (Hordeum vulgare L.). American-Eurasian Journal of Agricultural \& Environmental Science; 2008. 3(6): 855860 .

[142] Shen J., Yuan L., Zhang J., Li H., Bai Z., Chen X., Zhang W., Zhang F. Phosphorus Dynamics: From Soil to Plant. Plant Physiology; 2011. 156: 997-1005.

[143] Wang X., Yan X., Liao H. Genetic Improvement for Phosphorus Efficiency in Soybean: A Radical Approach. Annals of Botany; 2010. 106: 215-222.

[144] Rengel Z., Marschner P. Nutrient Availability and Management in the Rhizosphere: Exploiting Genotypic Differences. New Phyt; 2005. 168: 305-312.

[145] Fageria NK., Baligar VC., Li YC. The Role of Nutrient Efficient Plants in Improving Crop Yields in the Twenty First Century. Journal of Plant Nutrition; 2008. 31: 1121-1157.

[146] Miyasaka C., Habte M. Plant Mechanisms and Mycorrhizal Symbioses to Increase Phosphorus Uptake Efficiency. Communications in Soil Science and Plant Analysis; 2001. 32: 1101-1147.

[147] Zhao J., Fu J., Liao H., He Y., Nian H., Hu Y., Qiu L., Dong Y., Yan X. Characterization of Root Architecture in an Applied Core Collection for Phosphorus Efficiency of Soybean Germplasm, Chin. Sci. Bull; 2004. 49: 1611-1620.

[148] Miklas PN., Kelly JD., Beebe SE.Blair MW. Common Bean Breeding for Resistance Against Biotic and Abiotic Stresses, from Classical to MAS Breeding. Euphytica; 2006. 147: 105-131.

[149] Doerge R. Mapping and Analysis of Quantitative Trait loci in Experimental Populations. Nature Reviews Genetics; 2001. 3: 43-52.

[150] Ramaekers L., Remans R., Rao IM., Blair MW., Vanderleyden J. Strategies for Improving Phosphorus Acquisition Efficiency of Crop Plants. Field Crops Research; 2010. 117: 169-176. 
[151] Lopez-Bucio J., de la Vega OM., Guevara-Garcia A., Herrera-Estrella L. Enhanced Phosphorus Uptake in Transgenic Tobacco Plants That Overproduce Citrate. Nature; 2000. 18: 450-453.

[152] Zimmermann P., Zardi G., Lehmann M., Zeder C., Amrhein N., Frossard E., Bucher M. Engineering the Root-soil interface Via Targeted Expression of a Synthetic Phytase Gene in Trichoblasts. Plant Biotechnol. J.; 2003. 1: 353-360.

[153] George TS., Richardson AE., Hadobas PA. Simpson RJ. Characterization of Transgenic Trifolium subterraneum L. which Expresses phyA and Releases Extra-cellular Phytase, Growth and Phosphorus Nutrition in Laboratory Media and Soil. Plant Cell Environ.; 2004. 27: 1351-1361.

[154] George TS., Simpson RJ., Hadobas PA. Richardson AE. Expression of a Fungal Phytase Gene in Nicotiana tabacum Improves Phosphorus Nutrition of Plants Grown in Amended Soils. Plant Biotechnol. J.; 2005. 3: 129-140.

[155] Lung S., Chan W., Yip W., Wang L., Young EC., Lim BL. Secretion of Beta-propeller Phytase from Tobacco and Arabidopsis Roots Enhances Phosphorus Utilization. Plant Sci.; 2005. 169: 341-349.

[156] Li G., Yang S., Li M., Qiao Y., Wang J. Functional Analysis of an Aspergillus ficuumphytase Gene in Saccharomyces cerevisiae and its Root-specific, Secretory Expression in Transgenic Soybean Plants. Biotechnol. Lett.; 2009. 31: 1297-1303.

[157] Ma X., Wright E., Ge Y., Bell J., Yajun X., Bouton JH. Wang Z. Improving Phosphorus Acquisition of white Clover (Trifolium repens L.) by Transgenic Expression of Plantderived Phytase and Acid Phosphatase Genes. Plant Sci.; 2009. 176: 479-488.

[158] Wasaki J., Maruyama H., Tanaka M., Yamamura T., Dateki H., Shinano T., Ito S., Osaki M. Overexpression of the LASAP2 Gene for Secretory Acid Phosphatase in White Lupin Improves the Phosphorus Uptake and Growth of Tobacco Plants. Soil Sci. Plant Nutr.; 2009. 55: 107-113.

[159] Zamani K., Sabet MS., Lohrasebi T., Mousavi A., Malboobi MA. Improved Phosphate Metabolism and Biomass Production by Overexpression of AtPAP18 in Tobacco. Biologia; 2012. 67/4:713-720.

[160] Park MR., Baek SH., de los Reyes BG. Yun SJ. Overexpression of a High-affinity Phosphate Transporter Gene from Tobacco (NtPT1) Enhances Phosphate Uptake and Accumulation in Transgenic Rice Plants. Plant Soil.; 2007. 292(1-2): 259-269.

[161] Tesfaye M., Temple SJ., Allan DL., Vance CP. Samac DA. Overexpression of Malate Dehydrogenase in Transgenic Alfalfa Enhances Organic Acid Exudation Synthesis and Confers Tolerance to Aluminum. Plant Phys.; 2001. 127: 1836-1844.

[162] Yang H., Knapp J., Koirala P., Rajagopal D., Ann Peer W., Silbart LK., Murphy A., Gaxiola R. Enhanced Phosphorus Nutrition in Monocots and Dicots Overexpressing a Phosphorus-responsive Type I $\mathrm{H}^{+}$-pyrophosphatase. Plant Biotechnol. J.; 2007. 5: 735745.

[163] Delhaize E., Taylor P., Hocking PJ., Simpson RJ., Ryan PR., Richardson AE. Transgenic Barley (Hordeum vulgare L.) Expressing the Wheat Aluminium Resistance Gene (TaALMT1) Shows Enhanced Phosphorus Nutrition and Grain Production When Grown on an Acid Soil. Plant Biotechnol. J.; 2009. 7(5): 391-400. 
[164] Mohan J., Suprasanna P. Induced Mutations for Enhancing Nutrition and Food Production. Geneconserve; 2011. 40: 201-215.

[165] Liu J., Li Y., Tong Y., Gao J., Li B., Li J., Li Z. Chromosomal Location of Genes Conferring the Tolerance to Pi Starvation Stress and Acid Phosphatase (APase) Secretion in the Genome of Rye (Secale L.) Plant and Soil; 2001. 237: 267-274.

[166] Ahmed S. Agriculture-Fertilizer Interface in Asia-Issues of Growth and Sustainability. New Delhi. Oxford and IBH Publ. Co.; 1995 